JIM

ISSN: 2183-0606

(CC BY 3.0)

Vol. 9, 4 (2021)

p. $98-126$

AM: Dec/2021

SM: Oct $/ 2020$

\title{
The Impact of Emotional Experiences of Innovation Champions on Innovation Outcomes
}

\author{
Christina Swart-Opperman ${ }^{1}$, Babar Dharani ${ }^{2}$, and Kurt April ${ }^{3}$ \\ ${ }^{1}$ Faculty of Commerce, Graduate School of Business, Allan Gray Centre for Values-Based Leadership, \\ Cape Town, South Africa |cso@mweb.com.na \\ ${ }^{2}$ Faculty of Commerce, Graduate School of Business, Allan Gray Centre for Values-Based Leadership, \\ Cape Town, South Africa| babar.dharani@uct.ac.za \\ ${ }^{3}$ Faculty of Commerce, Graduate School of Business, Allan Gray Centre for Values-Based Leadership, \\ Cape Town, South Africa|kurt.april@uct.ac.za
}

\begin{abstract}
We considered the innovation champion as an internal role player, soliciting support for innovation and thereby influencing outcomes, and explored the influence of emotions of innovation champions while roleplaying on innovation outcomes. A Sub-Saharan African context was chosen as the internal- and external environmental instabilities exacerbate the demands and emotional experiences of innovation champions. Using a hermeneutic phenomenology methodology, the interview data of twenty innovation champions were coded using thematic and emotional coding techniques (Saldaña, 2013). The findings contribute to theory by (1) proposing the addition of the dimension of champions emotions when role acting to the conceptual framework (Shea, 2021) (2) revealing the prominent emotional experiences of innovation champions that impact innovation outcomes, and (3) present potential antecedents of the novel dimension. The fluid description and role of champions solicit emotional consequences for innovation champions with practical implications on innovation outcomes. Theoretically, they act as vital stumbling blocks for a scholarly consensus regarding whether such roles are over- or underrated.
\end{abstract}

Keywords: Innovation Champion; Champion Identity; Champion Emotional Experience; Champion Role.

Cite paper as: Swart-Opperman, C., Dharani, B., April, K., (2021). The Impact of Emotional Experiences of Innovation Champions on Innovation Outcomes, Journal of Innovation Management, 9(4), 98-126.; DOI: https://doi.org/10.24840/2183-0606_009.004_0006

\section{Introduction}

Innovation outcomes are influenced by different antecedents within the external and internal environments of organisations; however, the requirements for the successful adoption and implementation of innovation projects remain a much-debated issue in the research literature. While the role, impact, and importance of the innovation champion have been recognised by innovation scholars, especially in creating the context for the adoption (Sergeeva, 2016) and successful implementation (Pinto and Patanakul, 2015) of innovation, their influence is not universally recognized in the meta-study as a homogeneous antecedent for innovation implementation success (Singh et al., 2020).

A primary reason for the above lies in the varied definitions of innovation champions in the literature. Definitions range from organisations that lead innovation for an industry (Østergaard, 2019) to the employees within an innovation team (Barnhill et al., 2021) or an organization. Even within scholars who regard innovation champions to be personnel, there is an array of perspectives, 
ranging from those employees who are formally assigned the administrative task for innovation projects, those 'bred' by senior management (Howell, 2005), or human resources management practices (De Leede \& Looise, 2005), those naturally intrapreneurial who informally innovate (Curtis et al., 2020), to members of senior leadership teams who formally lead innovation in the organization (Papadakis \& Bourantas, 1998). We considered the innovation champion as an internal role player, soliciting support for innovation and thereby influencing outcomes for our study. Such champions have the potential to directly impact innovation projects by providing ideas, demonstrating enthusiasm, soliciting support, forming and motivating a team, mobilising resources, and also protecting projects from termination (Howell et al., 2005; Markham, 2013).

Even when adopting a specific definition of innovation champions, generalizing the behavioural requirements that support successful innovation outcomes presents a challenge due to the significant impact of contextual differences (Shane et al., 1995), of both the external- and internal environments of an organization. For example, technological developments (Bartlett, 2017), coupled with exponential growth in competition, customer sophistication and globalisation (Govindarajan and Trimble, 2010) present external forces to innovation within an organisation. Similarly, internal factors in their organisations, such as organisational support experienced by the innovation champion (Shea, 2021), insufficient or loose innovation agendas and strategies, intensified by a lack of focused leadership for innovation (Taylor, 2006), also impact champions.

In addition to the internal and external environmental influences, the attributes of the innovation champion, such as the innovation champion's beliefs regarding the innovation (Shea, 2021) and their personality (Bates et al., 2021), present an additional source of influence on innovation outcomes. The interactions between the three (innovation champion's attributes, internal- and the external organisational environment) generate significant complexities for identifying factors that support or hinder innovation progress (Rothwell, 1992; Hendy and Barlow, 2012; Walter et al., 2011). For example, dynamics between the individuals and their teams (Damanpour and Schneider, 2006; Kelley and Littman, 2006), the multi-faceted nature of organisational innovation processes, coupled with the innovation trends of the industry represent such a scenario of multi-level complexities

These complexities make it difficult to determine the value-addition of the champion role; thus, lead to challenges in assigning successes or failures of innovation agendas and strategies to successful or unsuccessful champions. In this regard, Shea and Belden (2016) highlight that the extent and reasons for the failure of innovation projects, even when a champion was involved, seem unclear. No overwhelming evidence supports the assertion that champions have a direct impact on or influence execution by project implementation teams (Howell and Boies; 2004; Howell et al., 2005; Hendy and Barlow, 2012), or that they necessarily contribute to organisational innovation success (Walter et al., 2011) or sustainability in service development (Wade and Elliott, 2012). However, this view is not shared by Jenssen and Jørgensen (2004, p. 64), who refer to "the significant impact of innovation champions on innovation success", and Bankins et al. (2016) emphasise the importance of the champion or innovation agents for public sector innovation, especially to overcome stumbling blocks to innovation at various organisational levels. Within scholarly perspectives which acknowledge the value-addition of innovation champions, specific champion characteristics and behaviour that support positive innovation outcomes further contribute to the continuous debate in the research literature (Rothwell, 1992; Heng et al., 1999; Esteves and Pastor-Collado, 2002; Howell et al., 2005; Coakes and Smith, 2007; Röst et al., 2007; Kelley and Lee, 2010).

While Shea's (2021) conceptual framework highlights the current consensus in the current literature regarding the dimensions of innovation champion, including commitment, experience, 
self-efficacy, beliefs about the innovation, support from the organisation, little is understood about the clusters of emotions that the champions experience during their involvement in an innovation project and how these influence and impact innovation outcomes. Several scholars have affirmed that emotions impact most human behaviour, for example, cognition, decision-making, motivation and attentiveness as well as psychological behaviour, such as attitude and perception (Davidson, 2003; Arntz et al., 2005; Izard, 2007; Algoe and Fredrickson, 2011). However, the literature on innovation champions lacks an acknowledgement and understanding of the impact of champions' emotions when acting in their role as champions.

To investigate this gap in the literature, a Sub-Saharan African context was deemed as the context that presents innovation champions with limited predictability of the internal- and external environments (Cilliers \& Aucoin, 2016), which need to be manoeuvred by the champions; thus, exacerbating the internal demands from the champions. This study analysed data from a convergent mixed-methods study by Swart-Opperman and April (2018) that focused on a JSE-listed Southern African insurance-based financial services company (referred to in the study as the International Case), which was active in 11 African countries at the time of the study. Secondly, ten innovation champions from three independent financial services companies from Namibia (referred to as the National Case) also participated.

We examined emotional experiences of innovation champions when role acting, using the affect theory of social exchange (Lawler, 2018), the affective events theory (Weiss and Cropanzano, 1996) as well as the multi-level model of emotions (Ashkanasy and Ashton-James, 2005) to contribute a novel dimension to the conceptual framework (Shea, 2021). The data were analysed to understand the emotions of innovation champions that could impact innovation outcomes and adoption. The article concludes with the presentation of an amended conceptual framework. The purpose is to make theoretical and practical contributions towards understanding the impact of the champion's emotions on innovation project outcomes.

\section{Theoretical Framework}

\subsection{Innovation Literature}

The champion is often linked as a key role player to specific projects, especially during the acceptance phase (Heng et al., 1999), and when radical change is implemented (Röst et al., 2007). Even though Shea and Belden (2016) offer a different opinion, in that the champion and the change agent are different concepts, the champion's role in change processes must be clarified and defined. At a meta-level, three roles of "a passionate idea champion, an investment champion who embraces innovation as a strategic tool, and an interaction champion that facilitates the process of innovating through timely internal and external connections" are suggested (Beckett \& Berendsen, 2015, p. 1). However, despite defining the meta-level role, the argument which had prevailed that "no single theory provides a foundation or a comprehensive understanding of such a role" (Jenssen and Jørgensen, 2004, p. 64), continues, as evident from Shea and Belden's (2016 p. 2) statement that "the current state of the literature on (HIT) champions is unclear". In addition, extant innovation literature offers differing and sometimes conflicting views on the definition and delineation of the innovation champion's role and responsibilities (Shane et al., 1995; Taylor, 2006; Sergeeva, 2016).

In a benchmark definition of an innovation champion, Howell (2005) highlights the spontaneous emergence of the champion role and that the champion supports the innovation effort visibly and energetically. However, Jenssen and Jørgensen (2004) indicate a formal process for the appointment of champions. Furthermore, the impression is often created that the champion 


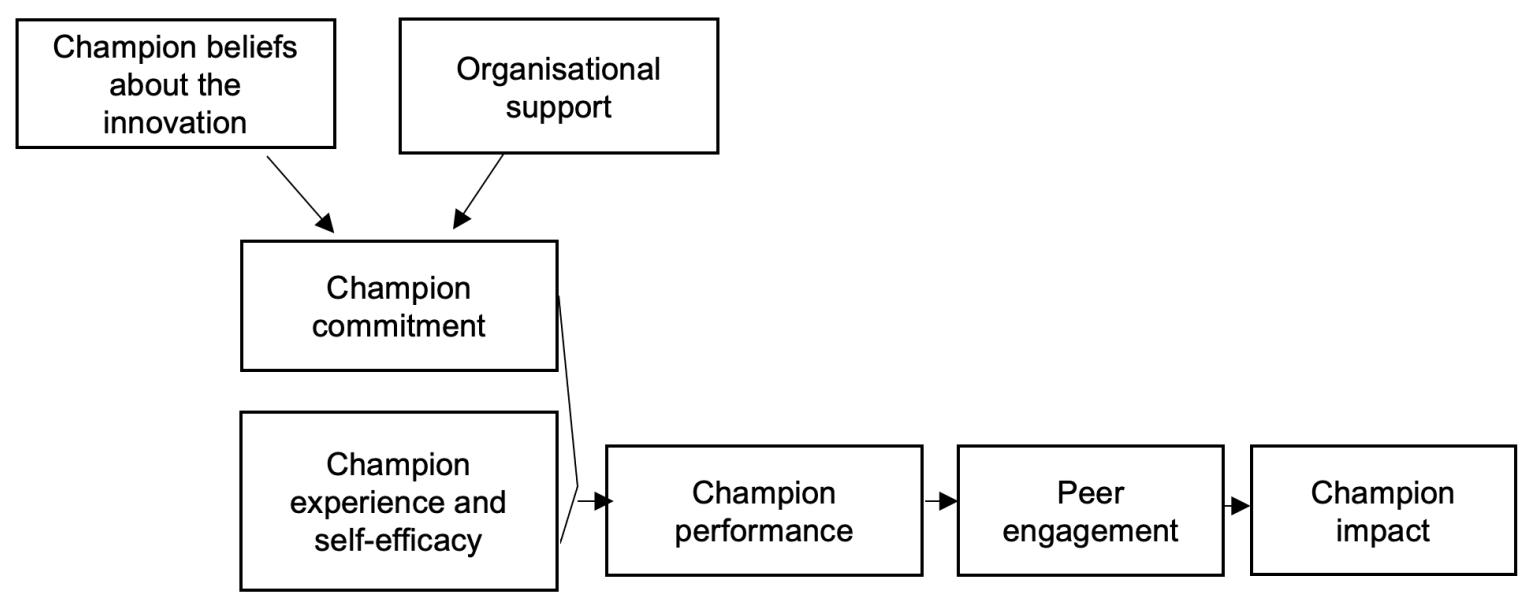

Figure 1. Conceptual model of innovation champion impact with selected dimensions (Shea, 2021).

can guarantee the successful adoption of the innovation project. As champions usually operate on the periphery of the innovation team (Howell et al., 2005; Kelley and Lee, 2010), they are often perceived to support and promote the innovation (Howell and Boies, 2004; Sergeeva, 2016). Coakes and Smith (2007), as well as Klerkx and Aarts (2013, p. 3), make the interesting further observation that champions are instrumental in the development of "Communities of Innovation (Colnv)" that are catalysts for and contribute toward the promotion and support for innovation projects. Furthermore, a combination of personal commitment, experience and self-efficacy is deemed necessary, as the champion cannot always rely on his/her personal expertise to fulfil this role (Shea, 2021)). As illustrated in Figure 1, this implies that the champion's commitment, to some extent, could compensate for the lack of expertise. However, increasing technological demands have exacerbated instances where insufficient expertise presents a stumbling block to the success of the champion, which implies a greater need for commitment. It can also be expected that this will lead to adverse emotional experiences and behaviour patterns by champions - such as feelings of increased insecurity, uncertainty and frustration.

Views on the required hierarchical level at which to pitch the innovation champion role also vary widely. A favoured view is that champions emerge from executive levels due to the high expectations attached to this role (Rothwell, 1992; Heng et al., 1999; Damanpour and Schneider, 2006; Govindarajan and Trimble, 2010; Klerkx et al., 2013; Garud et al., 2015; Sergeeva, 2016) and that the champion should be able to function beyond any bureaucratic and disciplinary constraints imposed by the organisation (Shane et al., 1995; Hendy and Barlow, 2012). A contrasting view offered by Birkinshaw et al. (2008), as well as Kelley and Lee (2010), is that champions need not necessarily emerge from the executive echelons but can come from different levels in a hierarchy whose creativity needs to be bred (Howell, 2005), fostered (De Leede \& Looise, 2005) and supported by senior management. However, we believe champions will experience great difficulty in performing their role if they are not hierarchically pitched at the executive level - for the reasons mentioned by those who argue in favour of this position. Alternatively, due to technological demands, it can be postulated that champions will be increasingly sourced from different levels in organisations or even externally. Thus, the role of the innovation champion remains blurred, fluid and vaguely defined, with no formal allocation within the organisational hierarchy (Kelley and Lee, 2010). The above presents fundamental differences for foundationally assigning an identity to champions, which implies a lack of power, influence and autonomy for the position. Consequently, the champion lacks the required authority to create space for employees to innovate and acts 
more as an "informational leader" (Howell and Boies, 2004, p. 657). One can therefore postulate that such factors could lead to certain emotional experiences of the champion, which impact their behaviour, as well as on the adoption of the innovation.

Different typologies exist to refer to the role of the champion and certain organisational expectations of champion activities are linked thereto (Shea and Belden, 2016), or disciplinary expertise (Sergeeva, 2016). This implies different role-based powers and focus areas, as well as possible barriers to overcome (Klerkx et al., 2013). Typical role references include administrative champion, gatekeeper, project manager, expert/power/technology champion, hybrid champion, relationship and supporter champion, saviour and organisational champion, internal change agent/project advocate, policy entrepreneur, and project owner (Rothwell, 1992; Gemünden et al., 2007; Röst et al., 2007; Birkinshaw et al., 2008; Shaw et al., 2012; Pinto and Patanakul, 2015; Shea and Belden, 2016). Esteves and Pastor-Collado (2002), as well as Taylor (2007), propose that the project manager and project champion be considered as two separate positions because they have different responsibilities and skillsets. Finally, the role of the champion is described as "supportive" by Pinto and Patanakul (2015), who point out that the champion could be either internal or external to the team.

In addition to the different typologies and expectations, further complexities emerge when the champion either fulfills several roles simultaneously or more than one champion (but in different roles) are involved in the same project (Shane et al., 1995; Shaw et al., 2012; Klerkx et al., 2013). Shane et al. (1995) and Gendron (2004) also observe the potential impact of national and organisational cultures, as well as values, on identity formation. Such impacts are expected to increase in the current internationalisation of the global workplace. Sergeeva $(2016, p .85)$ also points out that "the role of context is important in understanding an innovation champion's identity", whilst social and organisational environments add to complexities associated with identity, especially the level of demand for innovation (Howell and Boies, 2004; Birkinshaw et al., 2005; Govindarajan and Trimble, 2010). Therefore, it is suggested that context and culture impact the emotional experiences of champions and their subsequent behaviour.

An additional dynamic is that with innovation champions the organisational identity seems to be stronger than the group identity (Hendy and Barlow, 2012), as they function more at the periphery of the innovation team. Sergeeva (2016) adds to the debate with a study on innovation champion identity within the United Kingdom's construction industry from a social identity perspective. This study revealed that champion identity is both self- or other-constructed, i.e. it is possible that the identity of the role of champion could be conferred on an individual by others.

The individual profile of the innovation champion is often reflective of identity, especially via typically preferred behaviour and psychological characteristics. However, it is challenging to refer to an ideal profile of a champion as such descriptors are often based on the individual champion's perspectives and the context concerned (Sergeeva, 2016). Indeed, specific attributes that have been linked to successful innovation champions are reflective of human- and social capital (Jenssen and Jørgensen, 2004). For example, Yoho, Ford, Edvardsson, \& Dahlinger (2018, p. 94) promote an innovation champion to have: “. . . an obviously agile mind that could analogize new applications of older ideas" and Shea (2021) incorporates experiences (knowledge capital) and self-efficacy (psychological capital); thus, referring to different attributes required which correspond to various capital. A review of the literature regarding attributes of innovation champion and their categorization into different types of capital which are summarised in Table 1 (Rothwell, 1992; Nahapiet and Ghoshal, 1998; Heng et al., 1999; Gendron, 2004; Howell and Boies, 2004; Howell et al., 2005; Coakes and Smith, 2007; Röst et al., 2007; Kelley and Lee, 
2010; Walter et al., 2011; Yunicheva and Luna, 2012; Klerkx et al., 2013; Pinto and Patanakul, 2015; Shea and Belden, 2016; Curtis, Chui, \& Pavur, 2020; Shea, 2021). Foundationally, the champion's belief regarding arising from the strength of the evidence of the relative advantage it poses to the organisation, and its feasibility (compatibility with the organisation and a manageable level of complexity) bears a fundamental influence on the innovation champion's level of motivation, which influences the extent of 'capital' employed by the champion, ranging from intrapsychological, knowledge, organisational, and social capitals available to the innovation champion.

Table 1. Attributes of innovation champions

Type of attribute required

\begin{tabular}{l} 
Beliefs about innovation (C \\
\hline Intra-psychological \\
(Intra-psychological capital)
\end{tabular}

Descriptive words/characteristics

Evidence strength

Relative advantage

Compatibility

Complexity

Abundance mentality

Courage

Change tolerance

Enthusiasm

Energetic and achievement orientated

Knowledge pliability and open-minded

Persistence and resilience

Positivity

Resourcefulness

Risk-tolerance

Self-efficacy

Technical skill requirements

Analytical decision-making skills

(Knowledge capital)

Environment-scanning skills

Prior innovation/change experience

Technical skills in using the innovation

Professional skills as a champion

Organisational-level requirements

(Organisational capital)
Deep project and organisational commitment

Strong organisational identity

Organisational and project knowledge

Stress buffer/protector

Promoter of innovation ideas

Political sensitivity

Facilitation of cooperation

Networking skills

Influencing skills

Intrapreneurial

Context creation for teams

Cultural intelligence

Educate

Rapport-building skills

Team-building skills 
Type of attribute required

Interpersonal-level requirements

(Social capital)
Descriptive words/characteristics

Assertiveness

Emotional intelligence

Communication skills

While the innovation champion's attributes summarised from the literature review in Table 1 firstly address cognitive assessments of the champion regarding his/her beliefs about the innovation, emotions arising from such an intellectual assessment are exclusively founded on cognition. As such, it is noted that emotions founded on affect are absent in the conceptual framework. As such, from an emotions point of view, it presents a partial assessment of the emotional capital (Dharani, 2021), which does not address (1) affective emotional experiences of the innovation champion (2) the generalized (non-specific to the innovation) emotional capital of the innovation champion. Other cells in Figure 1 identify some facets of the generalized emotional capital (such as emotional intelligence, cultural intelligence, and stress buffer/protector), but neither the current literature nor the conceptual framework addresses the first gap identified above of affective experiences of innovation champions. For example, they lack reference to engagement of a champion (Maslach et al., 2001), resulting in dedication, absorption and vigour that an appropriate fit between the champion's cultural values and those of the organisation (Shane et al., 1995). Furthermore, they are insensitive to how the organisation positions authority and success (Shaw et al., 2012). As such, a gap in the literature that addresses the characteristics of innovation champions regarding the emotional capital, focusing on affect rather than cognition, is identified from the review.

\subsection{The Impact of Emotional Experiences on Successful Innovation Outcome}

The lens for this study is the Affect Theory of Social Exchange, as it "places mild, everyday emotions and feelings at the centre of the social exchange processes" (Lawler, 2018, p. 225). This theory is relevant to champions, as emotions are linked to knowledge exchange and individual achievement of goals, while dependent upon other people or groups. The Affective Events Theory (AET) of Weiss and Cropanzano (1996) also highlights that all behavioural displays of employees have an emotional and attitudinal basis, which is impacted by different variables in the work environment (Ashkanasy and Ashton-James, 2005), which could be either external or internal. Adapting the multilevel model of Ashkanasy (2003), Weiss and Cropanzano illustrate the potential consequences of emotions in organisations on five levels: the within-person; between-persons (individual differences), interpersonal relationships (dyads), groups and the organisation as a whole. In respect of a champion's management of a project, Poole (2004) points out that, besides the time and energy devoted to change and innovation processes, there is an emotional investment in them as well. This implies that the innovation champion will be, at least to some degree, have an emotional attachment to an innovation project. Moreover, the emotional experiences of the process of championing are often overlooked or underestimated; therefore, there is a danger of losing sight of the personal risk for the champion should the project fail (Shane et al., 1995).

Champions' unrealistic optimism and emotional attachment to a project often make it difficult to disengage when projects are completed. They then risk becoming 'bottlenecks' that hamper progress and evoke resistance from different stakeholders (Walter et al., 2011, p. 591). According to Hendy and Barlow (2012), this struggle to disengage from a project could relate to issues, such as an identity crisis caused by intra-psychological challenges the champion faces. Thus, when champions become affectively overcommitted (Meyer \& Allen, 1991) to a project, they might develop blind spots, which can have an adverse impact on its organisation and success. A champion's involvement in a project is a balancing act, and the champion should therefore not 
be perceived as 'over-performing' because it will imply that $\mathrm{s} /$ he finds it difficult to relinquish responsibility, which will dampen enthusiasm for the project (Wade and Elliott, 2016; Walter et al., 2011). The authors specifically mention a loss of self-image when the champion engages in detrimental behaviours that also undermine project success.

Another concern raised by Pinto and Patanakul (2015) are cases of narcissistic behaviour of project champions, which manifests in power displays that negatively impact project outcomes. Specifically, as narcissistic champions tend to personally overcommit to projects (even when a project becomes obsolete), they often fail to recommend termination of the project to protect their egos. Pinto and Patanakul (2015) also point out that champions who adopt destructive behavioural tendencies often behave in undue self-enhancing ways to the detriment of project progress and completion. They are "sending mixed signals to top management about the causes of the project's status" (p. 1184), reporting in a way that rather favours their reputation at all costs. Howell (2005) refers to such champions as having a negative outlook and an external locus of control and lacking emotional intelligence, while Govindarajan and Trimble (2010) refer to them as "defensive innovation leaders". In a longitudinal study by Howell (2005) that compares effective and ineffective champions, one of the findings is that ineffective champions lack sufficient confidence, enthusiasm, and persistence.

An additional dynamic is added with the simultaneous involvement of more than one champion in the same project. Shaw et al. (2012, p. 683) point to requirements both for the project champion and an organisational change champion in the healthcare industry. What is relevant to the argument presented here is that both have a reciprocal effect on each other and their emotions, and should they not be "aligned in their purpose and vision", the innovation project will be detrimentally affected. In their study Röst et al. (2007, p. 345) similarly refer to both project promoters and champions for the same project within the automotive industry; their finding is that it remains unclear "under which circumstances champions or specialists foster economic progress", i.e., the effect of such individuals may even be irrelevant.

In terms of internal and external factors, one can assume that if such factors elicit negative emotions, the champion's performance will also be impacted negatively. This will happen irrespective of the agent's performance capacity (Poole, 2004). From an organisational perspective, for example, one of the internal factors that have an adverse impact on champion emotions is the organisation's innovation process. When an innovation project is not assigned strategic importance or when the level of innovativeness among those involved is low, this creates an environment in which it becomes a challenge for the champion to perform (Kelley and Lee, 2010; Shane et al., 1995). A champion's performance is also suppressed by organisations that focus on current production routines and efficiencies at the expense of the innovation process and which compromise progress during the implementation of the innovation project (Röst et al., 2007; Shane et al., 1995). One potential solution to this is the proposal by Coakes and Smith (2007) that champions be supported socially and emotionally, be provided with sufficient resources, and receive recognition for what they do, to increase accountability for innovation outcomes.

Rothwell (1992) names certain external factors that impact champion performance, including the multi-faceted nature of innovation itself. Rothwell furthermore summarises several studies that highlight the importance of sensitivity to cues from the external environment and by extension marketing orientation, keeping track of technological developments and a focus on the customer. Besides the multi-faceted nature of innovation, there is also the fact that radical and incremental innovations require different champion behaviours. Radical innovation requires champions to display well-developed decision-making skills, while the requirements for incremental innovation champions are more about power, processes and relationships or being a technological gatekeeper 
(Röst et al., 2007). Should such requirements be overlooked, s/he could be technically challenged if differently inclined. The stage of the innovation process, or phase of the organisational lifecycle, can also impact champion behaviour. In this respect Howell et al. (2005, p. 644) refer to laterstage and early-stage champions, pointing out "that there may be degrees of the championship" in an innovation project.

Another external impact on a champion's success derives from project members or other organisational staff members who resist change and innovations (especially during the implementation phase) emotionally and cognitively (Howell, 2005; Klein and Sorra, 1996). Such resistance usually increases when innovations have a strong technical component and when employees lack sufficient information (Birkinshaw et al., 2005). If employees resist innovation, for example, because of a power struggle, they will not move out of their comfort zone when expected to adopt a change (Shane et al., 1995).

The culture within an organisation has an equally important impact on the performance of champions, especially in the presence of negativity and/or a lack of trust, (Röst et al., 2007), or when the innovation-values fit is inadequate for the higher authority group (Klein and Sorra, 1996; Pinto and Patanakul, 2015). In addition, different social cultures and values pose unique challenges to champions (Shane et al., 1995). A study by Kelley and Lee (2010, p. 1010) of 89 champions in Korean multinational organisations, and referring to the work of Hofstede (1985), emphasises the importance of the impact of national cultures on behaviour: "National culture characteristics can therefore add to the challenges champions encounter in seeking support and cooperation for their innovations." Kelley and Lee (2010) also highlight cultural intelligence as a definite requirement for successful champions.

\section{Methodology}

Certain dimensions leading to champion impact were selected in Shea's (2021) conceptual model. The dimension of affective experiences of innovation champions and their impact on innovation outcomes was not selected by the scholar, leading to an unavailability of a conceptual model for the dimension in the literature. As such, an inductive study was deemed appropriate, as the research required "analysing data with little or no predetermined theory, structure or framework and uses the actual data itself to derive the structure of analysis" (Burnard et al., 2008).

\subsection{Sampling}

A Sub-Saharan African context was well-suited for the research, as the lack of stability of internaland external environment (Cilliers \& Aucoin, 2016) imposes greater demands from the innovation champions in the skills, attributes and capitals borne by the innovation champions. In respect of the emotional journeys of the champion, a reduced internal- and external support weighs heavy on their emotional experiences. The study focused on an industry to avoid divergence of data that would result from analysis across industries. The financial services industry was chosen due to the availability of higher calibre and higher-ranking innovation champions to adhere to the definition of innovation champions adopted for the research. Within the financial services industry, a non-probabilistic sampling strategy was used as personal networks of the researchers were leveraged to gain access to the innovation champions. Thereafter, a snowball sampling strategy was followed to allow for data collection from outside the network of the researchers. To avoid some of the limitations imposed by the sampling strategy, a Namibia-based (National case) and pan-African (International case) demographic was ensured to enhance the generalizability of the findings beyond national borders. 
The researchers continued to approach innovation champions, and 22 participants were approached in total. The decision of saturation was founded on the fact that further dimensions of emotions were not gathered beyond the $6^{\text {th }}$ out of 10 participants in the international case and beyond the $9^{\text {th }}$ participant out of 10 participants in the national case, upon which further participants were not sought.

Based on the above sampling strategy, this study focused on a JSE-listed Southern African insurance-based financial services company (International Case), which was active in 11 African countries at the time of the study. It became one of the largest companies in South Africa when two large insurance-based companies merged in December 2010. Innovation was, amongst others, a company value, with a strong focus on growth and customers. The Chief Executive Officer at the time had emphasised the importance of innovation in Africa, specifically technology, innovative products and services for risk solutions, property investments, and innovative health provision. Ten innovation champions from six countries (Botswana, Kenya, Lesotho, Namibia, South Africa, and Zambia) were interviewed. Secondly, an additional ten innovation champions from three independent financial services companies from Namibia (National Case) were added to the sample. One company (founded in 1982 and listed on the NSX) is a leader in the financial services industry in Namibia, offering a wide range of financial products and services. The second company is a licenced insurer and carries out reinsurance business in Namibia, curbing capital outflow while stimulating economic growth. The third company is in operation since 1989 and formed an association with an internationally renowned audit and advisory firm in the year 2000 . Although this company has access to a global network of over 150 countries, the focus was on local service delivery.

\subsection{Method}

Since the qualitative approach aimed at uncovering the emotional experiences of the innovation champions during their time they held the role for the organisation, a hermeneutic phenomenology approach (Lauterbach, 2018) was taken to capture the lived experiences of innovation champions. There are no mandatory interviewer qualifications requirements for research conducted using hermeneutic phenomenology; nonetheless, a qualified industrial psychologist who is registered with the South African Health and Dental Council, with experience in studying emotions, conducted the interviews to ensure that not only the lived experiences, but the emotional experiences of the innovation champions were captured in the data.

The research received ethical clearance from the faculty, and all the relevant requirements, such as reasonable use of data, anonymity and protection of participants, right to withdraw, and the right not to answer any questions were adhered to (Bishop, 2009).

\subsection{Data Analysis}

The manual, verbatim transcription of interviews by the researcher allowed for greater proximity and first-hand knowledge. of the data After transcription, data were analysed twice using different techniques (Wästerfors et al. 2014). The first coding used N-Vivo software and adhered to the guidelines for hermeneutic phenomenological (Ho et al., 2017). The data were reanalysed, as per the recommendations of Wästerfors et al. (2014), namely to reread and recode the transcribed texts and "mobilize[d] a new engagement" (p. 473) that addressed the emotional experiences of the participants. The second coding was conducted by the interviewer using an "emotional coding" technique (Saldaña, 2013), which applies emotions to the interpersonal and intrapersonal experiences shared by the participants. It followed a manual, line-by-line coding system (Goulding, 2005; Creswell and Clark, 2011; Saldaña, 2013). The two data analyses were compared for 
triangulation. The consensus amongst both the analyses resulted in the final emotional experiences of the innovation champions, which formed the unit of analysis.

Using the dictionary of emotions (Ryan, 2014), the codes were then assigned to the text, capturing meaning through contemplation and integration (Starks and Trinidad, 2007) and utilising the classification of emotions as proposed by Sanders (2013) as presented in Table 2. The technique uses the identification of certain types of words and tones, and links them to the lived experiences shared by the participants for accuracy. The identified emotions were grouped into emotional sub-categories, emotional sub-themes, and emotional themes.

Table 2. Classification of Emotions based on Sanders (2013).

\begin{tabular}{ll}
\hline Emotion Category & Description \\
\hline Valence-based emotions & These emotions could be positive or negative. \\
\hline Approach-related emotions & $\begin{array}{l}\text { These emotions are goal-directed and positive in } \\
\text { nature. }\end{array}$ \\
\hline Social emotions & $\begin{array}{l}\text { These emotions are elicited in socially interactive } \\
\text { situations and regulate social behaviour. }\end{array}$ \\
\hline Moral emotions & $\begin{array}{l}\text { The object of moral emotions is the self, and they are } \\
\text { evoked by moral evaluations. }\end{array}$ \\
\hline Avoidance-related emotions & $\begin{array}{l}\text { These emotions are goal-avoidant in nature, and the } \\
\text { effort is called away from something. }\end{array}$ \\
\hline Counterfactual emotions & $\begin{array}{l}\text { Elicited by counterfactual thinking, these emotions } \\
\text { indicate an inappropriate choice between different } \\
\text { alternatives. }\end{array}$ \\
\hline Epistemic/Knowledge emotions & These emotions relate to knowledge and learning. \\
\hline
\end{tabular}

The transcribed interviews for the international and national cases were initially analysed separately and the results of both cases were subsequently combined for interpretation. Also, the champions were categorised as successful and unsuccessful, but this classification was abandoned due to the sensitivity of attaching such a label to them in their current work environments (Swart-Opperman \& April, 2018).

\section{Findings}

\subsection{The International Case}

The consensus from the two coding analyses for the International Case results are represented in Table 3. In total, 46 emotions were identified with a certain reported frequency for each identified emotion amongst the participants. The highest reported frequencies (15) were for emotions categorised as P (Positivity; Courage; Confidence). This was followed by Cu (Curiosity; Interest; Enthusiasm) (nine responses) and $D^{i}$ (Disappointment; Disgruntlement; Dismay; Reproachfulness; Displeasure) also with nine responses. Of the 97 reported frequencies for emotions, 48 were positive and 49 were negative.

\subsection{The National Case}

The consensus from the two coding analyses for the National Case results is presented in Table 4, and 28 emotions were identified with certain frequencies reported amongst the identified emotions. The emotions with the highest frequencies were S (Scepticism; Cynicism; Criticalness) followed by 
Table 3. Frequencies of Identified Emotions: International Case Identified Emotions.

\begin{tabular}{c|c|c|c|c|c|c|c|c|c|c|c|c|c|c|c|c|c|c|c|c|c|c} 
Participant & $\mathrm{S}$ & $\mathrm{D}$ & $\mathrm{I}$ & $\mathrm{N}$ & $\mathrm{C}$ & $\mathrm{A}$ & $\mathrm{F}$ & $\mathrm{D}^{\mathrm{i}}$ & $\mathrm{ID}$ & $\mathrm{LC}$ & $\mathrm{D}^{\mathrm{e}}$ & $\mathrm{D}^{\mathrm{ef}}$ & $\mathrm{P}$ & $\mathrm{T}$ & $\mathrm{C}^{\mathrm{l}}$ & $\mathrm{C}^{\mathrm{u}}$ & $\mathrm{H}$ & $\mathrm{P}^{\mathrm{a}}$ & $\mathrm{R}$ & $\mathrm{P}^{\mathrm{r}}$ & $\mathrm{A}^{\mathrm{b}}$ & $\mathbf{N}$ \\
\hline P1 & 4 & 1 & 1 & 1 & 1 & 3 & & & & & & & & 1 & & & & & & & & $\mathbf{1 2}$ \\
\hline P2 & & & & & & & 1 & & & & & & 4 & & 4 & 3 & 4 & 2 & 1 & & & $\mathbf{1 9}$ \\
\hline P3 & 1 & & 1 & & & 1 & 2 & 6 & & & & & 1 & & 1 & & & & & & & $\mathbf{1 3}$ \\
\hline P4 & & & & & & 1 & & & & & & & 1 & & & 1 & & & & 2 & & $\mathbf{5}$ \\
\hline P5 & & & & & 1 & & 1 & 1 & 3 & 1 & & & 1 & & & 3 & & & & & 1 & $\mathbf{1 2}$ \\
\hline P6 & 1 & & & 1 & & & & & & 1 & 1 & 3 & & 2 & 1 & 1 & & & 1 & 1 & $\mathbf{1 3}$ \\
\hline P7 & & & 1 & 2 & & & 1 & & & & & & & & & & & & & & & $\mathbf{4}$ \\
\hline P8 & 1 & & 1 & 1 & 2 & & 1 & 2 & & & & & 1 & & & 1 & & 1 & & & & $\mathbf{1 1}$ \\
\hline P9 & & & & & & 1 & & & & & & & 1 & & & & & & & 1 & & $\mathbf{3}$ \\
\hline P10 & & & & & & 1 & & & & & & & 3 & & & & & & 1 & & & $\mathbf{5}$ \\
\hline N & $\mathbf{6}$ & $\mathbf{2}$ & $\mathbf{4}$ & $\mathbf{4}$ & $\mathbf{5}$ & $\mathbf{7}$ & $\mathbf{6}$ & $\mathbf{9}$ & $\mathbf{3}$ & $\mathbf{1}$ & $\mathbf{1}$ & $\mathbf{1}$ & $\mathbf{1 5}$ & $\mathbf{1}$ & $\mathbf{7}$ & $\mathbf{9}$ & $\mathbf{5}$ & $\mathbf{3}$ & $\mathbf{2}$ & $\mathbf{4}$ & $\mathbf{2}$ & $\mathbf{9 7}$ \\
\hline
\end{tabular}

Key:

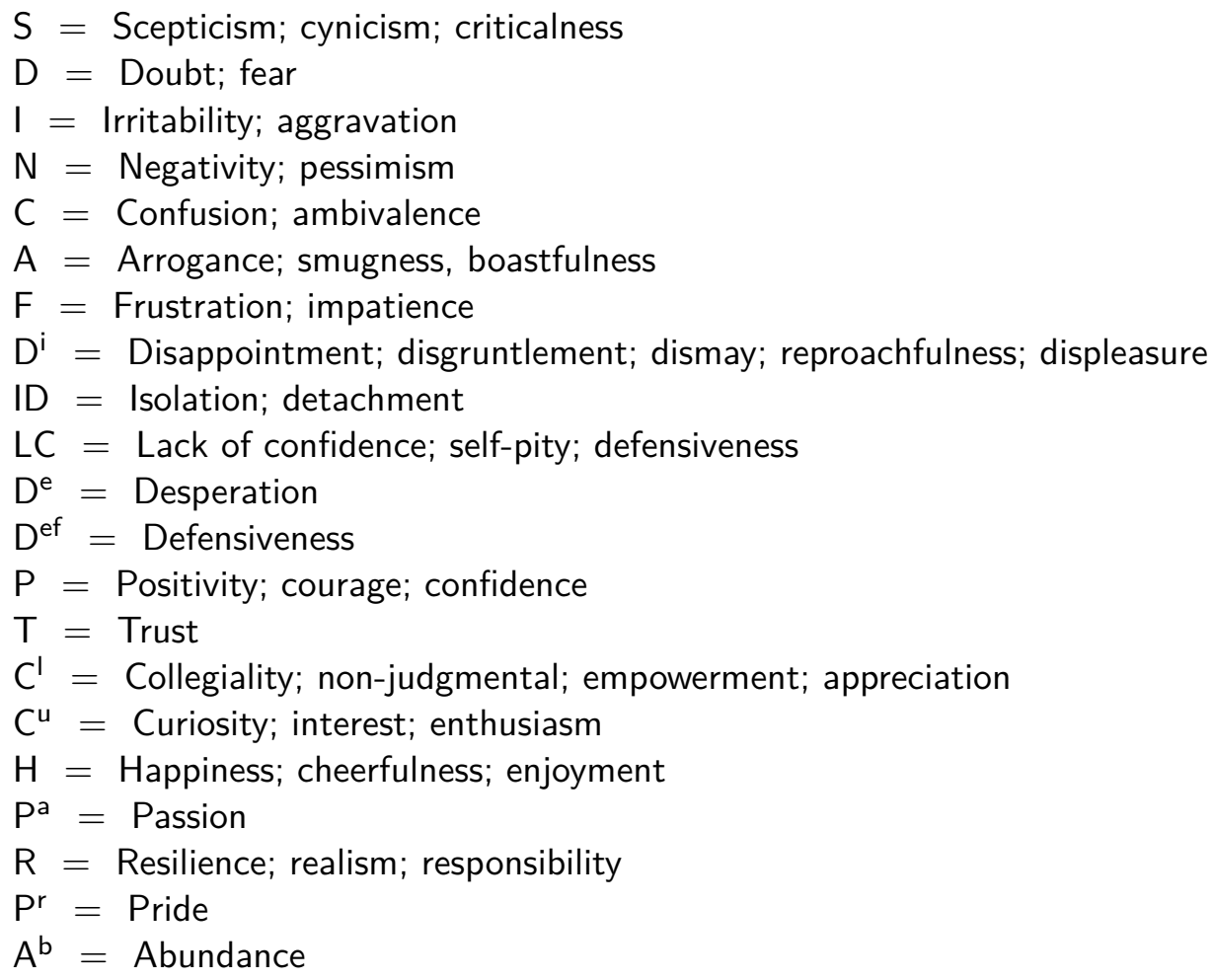


Table 4. Frequencies of identified emotions: National Case

\begin{tabular}{c|c|c|c|c|c|c|c|c|c|c|c|c|c} 
Participant & $\mathrm{S}$ & $\mathrm{N}$ & $\mathrm{C}$ & $\mathrm{F}$ & $\mathrm{P}$ & & $\mathrm{C}^{\mathrm{u}}$ & $\mathrm{P}^{\mathrm{a}}$ & $\mathrm{R}$ & $\mathrm{P}^{\mathrm{r}}$ & $\mathrm{A}^{\mathrm{b}}$ & $\mathrm{O}$ & $\mathbf{N}$ \\
\hline $\mathrm{P} 11$ & 1 & & & & 1 & & & & 1 & 2 & & 1 & $\mathbf{6}$ \\
\hline $\mathrm{P} 12$ & 1 & 1 & 1 & 1 & & & 2 & & & & 4 & & $\mathbf{1 0}$ \\
\hline $\mathrm{P} 13$ & 4 & 1 & & 1 & 1 & & & & 1 & & & 2 & $\mathbf{1 0}$ \\
\hline $\mathrm{P} 14$ & 1 & & & 1 & 1 & & & & & & & & $\mathbf{3}$ \\
\hline $\mathrm{P} 15$ & 4 & & & & 1 & & & & & & & 1 & $\mathbf{6}$ \\
\hline $\mathrm{P} 16$ & 2 & 1 & 1 & 2 & 2 & & 1 & & 1 & & & & $\mathbf{1 0}$ \\
\hline $\mathrm{P} 17$ & & 1 & & 1 & 1 & & & & 1 & 2 & & & $\mathbf{6}$ \\
\hline $\mathrm{P} 18$ & 4 & 2 & & & & & 1 & & & & & & $\mathbf{7}$ \\
\hline $\mathrm{P} 19$ & 2 & & 1 & & 2 & & 1 & 1 & & 1 & 1 & & $\mathbf{9}$ \\
\hline $\mathrm{P} 20$ & 5 & & & & 1 & & & 1 & & & & & $\mathbf{7}$ \\
\hline $\mathbf{N}$ & $\mathbf{2 4}$ & $\mathbf{6}$ & $\mathbf{3}$ & $\mathbf{6}$ & $\mathbf{1 0}$ & & $\mathbf{5}$ & $\mathbf{2}$ & $\mathbf{4}$ & $\mathbf{5}$ & $\mathbf{5}$ & $\mathbf{4}$ & $\mathbf{7 4}$ \\
\hline
\end{tabular}

Key:

$\mathrm{S}=$ Scepticism; cynicism; criticalness

$\mathrm{N}=$ Negativity; pessimism

$\mathrm{C}=$ Confusion; ambivalence

$\mathrm{F}=$ Frustration; impatience

$\mathrm{P}=$ Positivity; courage; confidence

$\mathrm{C}^{\mathrm{u}}=$ Curiosity; interest; enthusiasm

$\mathrm{P}^{\mathrm{a}}=$ Passion

$\mathrm{R}=$ Resilience; realism; responsibility

$\mathrm{P}^{\mathrm{r}}=$ Pride

$\mathrm{A}^{\mathrm{b}}=$ Abundance

$\mathrm{O}=$ Sense of being overwhelmed/stress

P (Positivity; Courage; Confidence) with 10 responses. Of the reported frequencies, 39 emotions were negative and 35 positive.

Emotional themes. Four emotional themes were elicited from the coding of interview transcriptions (Figure 1).

Theme 1: Collegiality reflects the innovation champion's emotions during role acting. The emotional sub-themes that emerged under Collegiality were Sociability that consists of the emotional sub-categories of Positive Valence-based Emotions, Approach-related Emotions and Social Emotions.

Theme 2: Pro-social Emotions with Moral Emotions as a sub-theme, consists of emotional sub-categories such as Compassion, Other-praising, Other-condemning, Feelings of Isolation, and Self-consciousness.

Theme 3: Disagreeableness encompasses three emotional sub-themes, namely Žal, AvoidanceRelated Emotions and Sense of being Overwhelmed.

Theme 4: Effectuation is reflective of Openness to New Experience as the Emotional Sub-theme and Epistemic/Knowledge Emotions as an emotional sub-category.

\section{Discussion}

\subsection{The Context}

Although both cases functioned in complex regulatory environments, the International Case 


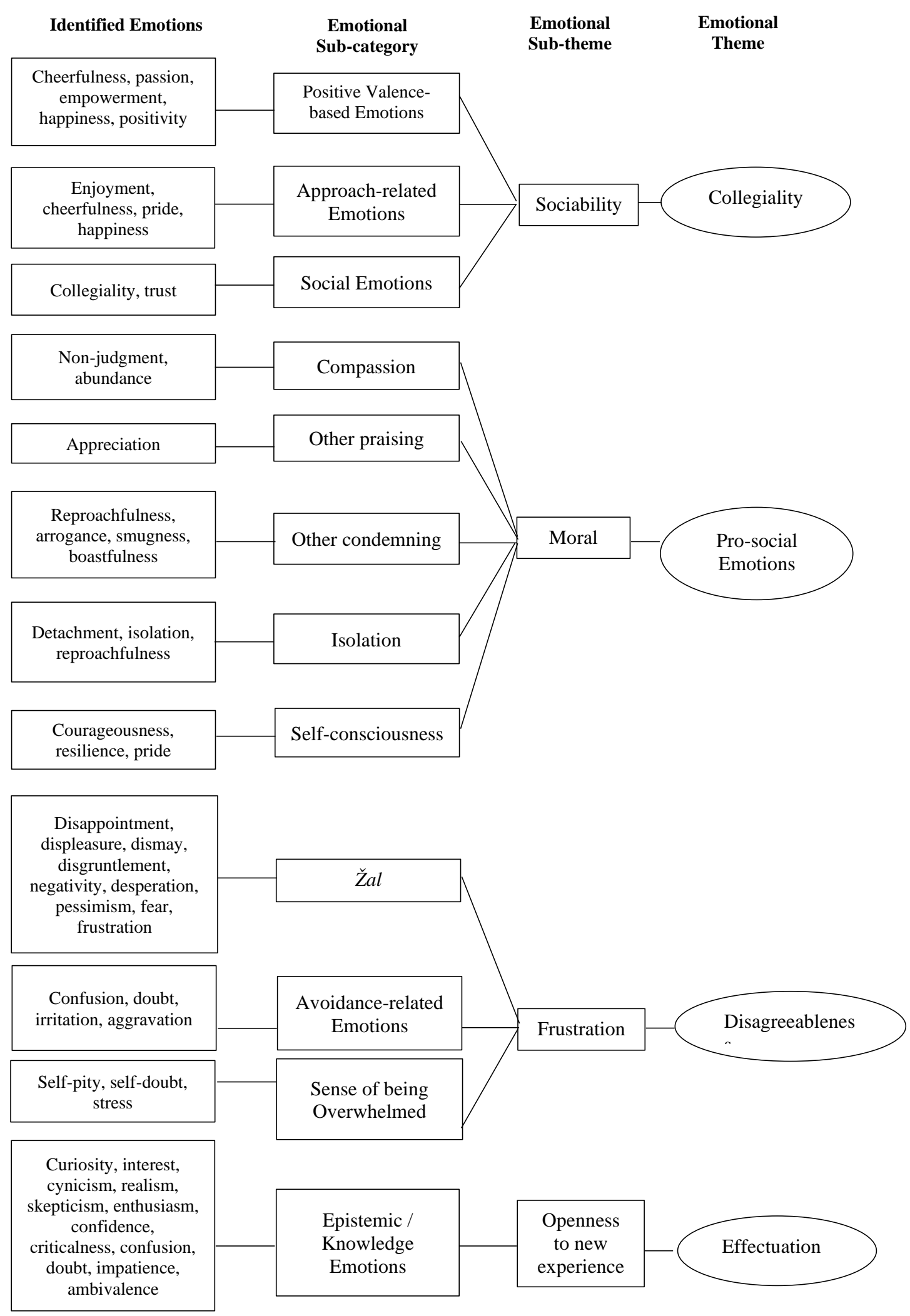

Figure 2. Emotional themes were identified and grouped based on the Dictionary of Emotions (Ryan, 2014) and an emotional coding technique (Saldaña, 2013). 
underwent a recent merger of two major role players in the financial services industry (SwartOpperman and April, 2018) that could have influenced the emotions they experienced. Overall, the participants expressed a wide range of emotions reflective of the informal corporate culture at the time. Contrarily, the National Case participants were impacted more by the reality of talent shortage in a smaller country such as Namibia. The range of emotions expressed was narrower, which could be attributed to the observed formal corporate culture.

For this discussion, Collegiality is defined as gezelligheid or gemütlichkeit, thus relating to feelings of congeniality and companionship (Smith, 2016, p. 113). Pro-social emotions are linked to a definition for prosocial behaviour as provided by Sanderand Scherer (2006, p. 315), which are emotions that are "generally beneficial to other people and the ongoing political system". Pro-social emotions may thus include positive emotions (compassion, other-praising or self-consciousness) or negative emotions (other-condemning or feelings of isolation). Disagreeableness stems from feelings of insecurity and anxiety, and follows a "disconfirmation of the prospect of a desirable event" (Sander and Scherer, 2006, p. 120). Based on the theory of effectuation we have linked the feelings that are experienced when new knowledge and opportunities are discovered and exploited to the theme of Effectuation (Read et al., 2008). It also relates to rumination, i.e., "recurrent instrumental thinking about an unresolved goal is triggered by a perceived discrepancy between the current state and the desired goal" (Sander and Scherer, 2006, p. 349).

\subsection{The International Case}

Collegiality. Champions describe several positive valence-based, approach-related and social emotions, despite the process and outcome of the merger that was experienced as negative. An example of an approach-related emotion is pride: "I think one of the key differentiators for us is that we are the only company that has an innovations department." (P3).

Some participants report high levels of positive valence-based emotions as a personal positive outlook. For example: "So, it is about how you look at life. Yes, it is asking what the opportunity here is, what I am missing, what would somebody else do here. So, look at the opportunity rather than the negativity - always my mantra." (P6). Such positive emotions also impact their view and role acting, as reflected in the robust customer-centric approach which P10 emphasises: "Yes, we are very good at servicing our customers". Others acknowledge that innovation improves operational efficiencies: "I am definitely excited about innovation as it makes our lives easier." (P8)

Emotions such as cheerfulness, enjoyment and pride influence champions' views of their roles and involvement with innovation and projects. P6 remarks:

"It is quite a nice process to be involved in. I am involved with the branding aspect in the unit and I have attended some of the sessions", whilst P4 observes that "I think, given the other countries, we are a step ahead." However, excessive pride and positivity could be indicative of surface acting amongst the champions and related to what Wade and Elliott (2012, p. 491) refer to as "enthusiastic promotion", where the champions remain enthusiastic despite adverse conditions.

Several participants report emotions of collegiality. P2 shares his viewpoint: "If you push the limit, you must accept that you will tread on people's toes. And when you do this, you must be gracious enough to ask for forgiveness. And a neighbourhood watch approach, yes, we are strong on that - you watch out for your buddy - the blind spot must be covered by you, because he is covering your blind spots."

Such feelings of collegiality could imply that these champions are inclined to focus on relationship building as an important part of the innovation process (Wade and Elliott, 2012). 
Effectuation. Effectuation has an openness to new experiences as a sub-theme and epistemic/knowledge emotions as an emotional sub-category. Participants feel that curiosity is an important aspect of a champion when role-acting: "I actually use the internet, I check what is happening in South Africa and Namibia, and just ensure that compliance-wise it is something that is allowable here (Botswana) and then pitch it through our product development team." (P5).

This is in line with the findings of Heng et al. (1999) who report the importance of vision and focus on needs and opportunities for 10 Dutch champions; this is likely to be reflective of curiosity, confidence and enthusiasm. Related to curiosity are interest, enthusiasm and openness to new ideas, and P10 goes on to say that:

"I would say I am a resource: technically speaking I think this is what I do for a living more or less. Because of the experience I have it is possible to anticipate three or four steps ahead of a current thinking process."

Howell (2005) reports that effective champions tend to explore new ideas and opportunities and have a wide field of interest. In addition, in their study of 47 innovation champions, Howell and Shea (2001) conclude that environmental scanning activities relate positively to champion behaviours. Furthermore, White and McGowan (2011, p. 387) report that nurse champions engage in similar activities such as "exploring, auditing, and monitoring of best practices". However, participants were cynical and critical about the company's approach toward innovation that leads to more exploration of different ideas and opportunities. This is reflected in the comment by P3: "So that is why, that is my criticism - I see people who at their very heart and essence are very bureaucratic and what they do in the end is that they do not innovate, but create further barriers."

Pro-social Emotions. The emotional sub-theme identified is moral emotions. Champions express feelings of compassion, and P1 is particularly non-judgemental towards his colleagues: "Yeah, I think it is very difficult to be innovative if you are constantly busy, with processes ad internal restructuring or stuff like that." In addition, P3 expresses feelings of abundance and a strong belief in the empowerment of team members because "they can excel in whatever they do, whether they work for this company or any other organisation, or their families or their communities." On the other hand, champions experience other-condemning emotions such as arrogance, smugness and boastfulness. P10 says: "Yeah, I mean in all things I try not to inject my personal opinion - that is my biggest struggle." P9 comes across as rather arrogant: "You can see in my current leadership role that innovation is a very sensitive and critical element that cannot be left to the middle or lower level."

Although feelings of isolation are also social emotions, we consider it a negative valence-based emotion, as it relates more to the view of the champions from the regions such as Namibia in relation to organisational isolation. P5 feels that: "they, whoever does it, does it in isolation and it is not really coordinated. Our involvement is where we give them information. My assumption is that they have parameters. But I do not know." Reproachfulness and displeasure were also evident and P3 and P8 remark: "So, the fact is us bringing products to market is really, really bad. Sometimes big companies just force decisions on staff and without understanding the reasoning behind [the] change."

Disagreeableness. Champions in the international case group hold negative perceptions of their companies' approach towards innovation. Emotional experiences reported are irritation, disappointment, frustration, and reproachfulness. They see their company's approach as reactive, undisciplined and lacking an appropriate agenda (P5, 6, 8 and 10). Aspects of the organisational culture experienced as negatively impacting innovation were instances of language use in the form of certain acronyms and industry buzzwords, as P6 puts it: "The company does not always know how to innovate and sometimes gets stuck on buzzwords, meetings, language ... We use all the 
right buzzwords, but we don't do anything - and we haven't built a single product market yet."

Feelings of irritation, criticism and disgruntlement could impact the champion's role positively in terms of prompting the exploration of different viewpoints. Alternative feelings of negativity also emanate from coping with constant change and uncertainty. P3 is outspoken about this and voices such emotions strongly: "Yes, the intention is there, but the way it has been executed. . let me give you a good example. We have created centres of excellence which should be cutting-edge products. The problem with that is, that since we have implemented that, the number of new products that we have taken to market has virtually dropped to zero."

Paternalism from a head office that clearly lacks sensitivity to regional nuances is another negative influence, leading to emotions of negativity and frustration. P7 says: "I think you can note this: currently the group is blocking innovation, because they operate on 'We - all [of] the business - needs to listen to us.' When we come up with ideas that can work for a country like $\mathrm{XYZ}$, it somewhere gets blocked. It is said, 'No, you guys, we have to do the same in all African countries.'".

Championing also seems to be affected by the different countries' apparent unwillingness to share information and power. This could be indicative of a lack of trust where "they protect their turf a bit, but innovation is not owned by anybody." (P2).

The culture of the organisation seems to be protective of established organisational routines and networks, which were probably preserved by the long tenure of some staff and team members. The comment by P6 is interesting in this regard because it implies that negativity and cynicism are associated with innovative thinking and behaviours: "I have seen ... if that disrupts the core business model that the organisation relies on, then the antibodies will come out and it will kill the idea."

Innovation champions and the innovation intent per se also seem to be impacted negatively after a merger, if it is managed poorly, resulting in feelings of insecurity and mistrust. In this regard, P7 notes the following: "Some companies will force down the change, like you have no say in what they want to do. And usually, what they want to implement, you know for a fact will not work."

Other organisational realities that consciously or unconsciously contribute towards a negative impact on champions relate to experiences of stress and role overload due to time pressure and unavailability of teams. Champions observe the following in this context: "Yeah, I think it is very difficult to be innovative if you are constantly busy, with processes and internal restructuring and stuff like that." (P1). And: "So if there is an innovation project on the side that perhaps is related but not quite linked to their core job, they do not have time for that." (P3).

Champions are also directly negatively impacted by the top leadership of their organisation, especially if their leadership style is perceived as authoritarian, if leaders are too status-conscious or, even, complacent. Certain toxic leadership behaviours, especially when leaders behave egotistically, are detrimental not only to champions, but also the organisation as a whole, as P1 notes: "If you don't use the right innovation-sounding and customer-centric descriptions, the people won't even engage with you."

A general undercurrent to the international case group is feelings of anxiety, a fear of change, and uncertainty. In addition, when leaders are blindfolded by an exaggerated sense of loyalty and a lack of passion for innovation and thus reluctant to make innovation part of the leadership agenda, they penalise participation in innovation. Such leaders seem to use performance appraisals punitively, e.g., instead of evaluating the achievement of core deliverables, they would focus on participation in the innovation project. 


\subsection{The National Case}

Collegiality. These champions experience positive valence-based as well as approach-related emotions, such as positivity, passion and pride. P14 gives an expanded view in the sense that "For me, it is quite easy - I believe that Africa can, I am an African at heart. I feel personally, yes, that we can definitely find solutions to our own problems." Both P16 and P20 share similar views in terms of Africa's potential for innovative growth, while P13 and P19 feel more positive about their company's and teams' abilities to cope with innovation or even their own positivity. P11 mentions that "I think I am always open to new ideas from team members. If they got an idea to do something differently which will improve effectiveness and efficiencies, then I am always open to do that and you can develop that in a team."

Of note is the passion and pride amongst these champions. For example, P17's pride is reflected in the following observation: "Over time you reflect that you gained the confidence of the market, clients and staff. You know, people were increasingly taking note of us, increasingly been prepared to move their accounts to us, to change jobs and leave the old."

Pro-social. Emotional sub-categories, such as compassion and self-consciousness are evident amongst the champions, P19, for example, is quite non-judgemental in his view: "One has to be fair to people - you might find an identical profiled person and they might be acting differently just because the stimulation from the environment is different." P12 expresses feelings of abundance and says that "I am for a position where we forget about the "isms" and we focus on our common care for each other and if we can think of it that way, it is like evolution."

The emotional sub-category of self-consciousness is also evident amongst them, especially resilience. For example, Champion 17 feels that "In short, I mean to use a cliché, it was simply hard work, focus and finding innovative ways in coping with all the challenges, within the scope and parameters of your ability."

Disagreeableness. Champions in the national case observe certain factors in the internal (organisational) environment that have an impact on their championing orientation, especially role overload, the nature of their professions (P16), and a lack of time for reflection. This results in a sense of being overwhelmed and stressed and P13 and P16 describe their frustration and being overwhelmed as follows:

"My profession is, you do the same thing over and over again ... You are so under stress to produce and with all the pressure on you, you can't think." And: "You are so under stress to produce and with all the pressure on you, you can't think. You do not have time to think you must just produce."

Several champions (P 12, 13, 14 and 15) experience established work routines as discouraging their innovation behaviour, since innovation is not viewed as a priority or essential to engage with the future. Some are also discouraged by the lack of talent available, both in the market and within their organisations, which detracts from their enthusiasm. P11 puts it this way: "The quality (of talent) that we get is relatively weak, so that the smallest improvement is not possible." And P12 voices his concern as: "I think it is the level of know-how we have. The level of education is a stumbling block - it is a big lack."

Champions are cynical of their respective organisations' apparent lack of understanding of what innovation means in their context, and denial of its urgency. Participating champions express these as follows: "Some people think innovation is just all about high-tech stuff and having drones." (P15), "Everybody drives it from their perspective, depending on their mental model, and not necessarily from the realities of the organisation." (P12), and: "No, everybody is well fed and there is not sufficient understanding or willing to even conceptualise that the world around us is actually in trouble." (P20). 
Others feel that their organisations lack the energy to implement innovation, although there was never a shortage of innovative ideas. Some participants are frustrated and also disillusioned by the leadership and thinking habits in companies: "So my view, it is the leadership, the people taking the decisions in the organisation have not bought into this whole concept of innovation trying different things, trying new things, changing for the better. The government can protect you only so long. I don't think that penny has dropped here yet and that is why there is the type of attitude that somebody will bail us out." (P16).

Also, in terms of the internal environment, negativity within the organisation as a whole is another detracting factor for innovation champions. The negative emotions identified are disillusionment, pessimism and cynicism: "I don't know, maybe we were not hungry anymore ... We became big, successful, and I do not know, maybe we just lost the hunger to do it." (P18), "People would do the same mistake just over and over. And it is as if they couldn't care less." (P17), or: "I think that is our biggest challenge. We do not implement very well; I think sometimes we over-plan for everything." (P20).

Other concerns noted in the internal environment are related to frustration due to system constraints (P19) and where people tend to behave in an apathetic or disengaged fashion (P17). Champions became frustrated by team members' reactiveness, i.e., instead of being proactive, they "are not looking ahead on how to improve it" (P16). This fosters feelings of insecurity, amongst others - mainly when consultants are used. Campions are frustrated by resistance to change, outdated mental models in terms of how industry forces operate and, therefore, what is required. Champions were disturbed by team members who were disruptive in meetings: "[...] and then we all get distracted by the red herrings and then we are losing focus" (P12).

They are cynical and frustrated about leadership's perception of innovation and the implied impact on innovation champions' innovation behaviour. Such leadership becomes potentially inhibiting when leaders lack passion and relied heavily on autocratic or self-leadership styles. This is how some of the participants put it: "I think leadership ... they haven't figured out how to drive innovation in this conservative, highly regulated environment." (P16), and: "And I am already seeing that there is some fragmentation, but I believe the fragmentation is around the leadership within the team. It is the leaders that create that lack of cohesion. So, what you have is people getting through the ranks and ending up in the senior management ranks. They are less inclined to do it [the innovation idea] than people who are coming from the bottom. So, what you have are people who are not driven by innovation and change, having to make it work." (P20).

For the external environment, participants feel that being in the financial services industry could be demotivating because of the high degree of control and client expectations, as well as ongoing technological developments and constantly changing rules. The intensity of competition, especially in terms of non-traditional participants' entrance into the market, is perceived as overwhelming, which in turn leads to the freezing of both innovative organisational behaviour as well as champion behaviour (P11, 15 and 19).

Effectuation. The same trend was reported as for the International Case - although fewer champions reported emotions such as curiosity, interest, and enthusiasm.

\section{Contributions and Practical Implications}

\subsection{Conceptual Framework}

Championing behaviour is discretionary and reflective of Bergh's (2014) description of pro-social organisational behaviour, namely positivity, commitment, and support of current organisational goals. Furthermore, championing behaviours link in closely with, or reflect, organisational 


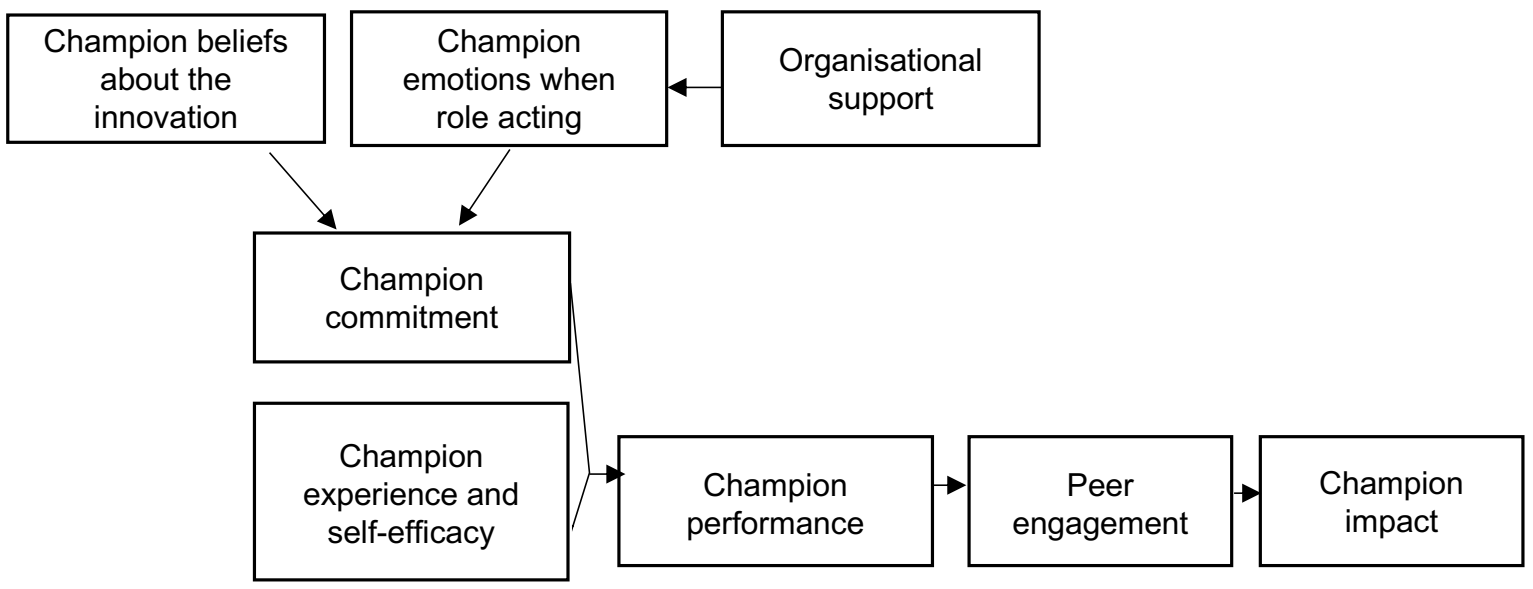

Figure 3. The proposed amended conceptual model of innovation champion's impact with selected dimensions (Shea, 2021), adding the dimension of Champion Emotions when Role Acting.

citizenship behaviour, as described by Organ (1997) and Smith, Organ and Near (1983). In light of these, the emotional experiences of innovation champions deserve acknowledgement as a significant dimension for innovation outcomes.

The first contribution of this article is the proposed addition of the dimension of 'Champion emotions when role acting' in Shea's (2021) conceptual framework. (Figure 2 illustrates the proposed position of the dimension in the conceptual framework (Shea, 2021). Our findings place this novel dimension at the same level on the figure as the dimension of "Champion beliefs about the innovation". This is founded on the principal that the dimension of "Champion beliefs about the innovation" in the framework represents a cognitive assessment of the innovation by the champion, which goes hand-in-hand with the affective response of the champion when role acting. The above positioning entails that the "Champion commitment" dimension is drawn from a combination of cognitive assessments of the innovation by the champion as well as the affective response of the experience during role-acting. This is supported by scholars in the field of commitment, which emphasise that emotions contribute toward affective commitment (Meyer et al., 2002). The positioning is also consistent with empirical research which suggests emotions precede performance (Zelenski et al., 2008). In conclusion, the position: (1) suggests champion emotions as an antecedent to champion commitment (2) Organizational factors, such as the dimension of "Organisational support", to form a prominent controllable antecedent for champion emotions when role acting.

Further to the proposed addition of the dimension to the conceptual framework, our inductive study contributes to theory by uncovering aspects of the dimension of the proposed "Champion emotions when role acting", including:

1) The prominent antecedents to the dimension include those that lie within the organisational context (Figure 4), such as:

(a) the formalisation of the champion's role. In some instances, champions emerge quite informally and as a result their role is ill-defined, triggering unforeseen negative emotions which impacts innovation outcomes.

(b) functional position within the innovation team. In many organisations, the functioning of the champion on the periphery of the team without a clear exit-point from the project or the role can trigger a level of emotional attachment to the innovation which negatively impact innovation completion. 


\begin{tabular}{|l|}
\hline Organisational Support \\
Context \\
Informal/formal emergence \\
into role \\
Function at team periphery \\
Hierarchical level \\
Informal/formal leadership \\
role \\
Organizational culture \\
Organizational events (e.g. \\
mergers)
\end{tabular}

\section{Champion}

Emotions when

Role Acting

Collegiality

Pro-social Emotions

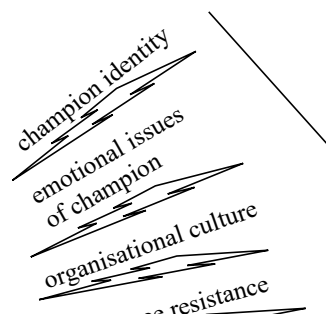

Disagreeableness
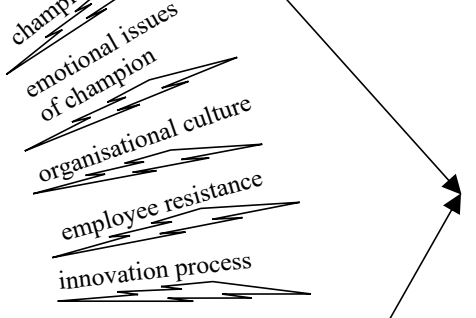

Disagreeableness

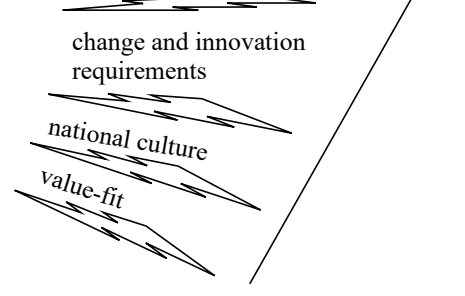

Outcomes

Effectuation

outcome/adoption

Figure 4. Context variability identified as antecedents, and prominent emotions of the innovation champion which impact innovation outcomes

(c) the champion's hierarchal level. The processes of identifying a champion within an organisation are insufficiently addressed in the research literature (Walter et al., 2011), while Hendy and Barlow (2012) note the lack of research evidence on the most appropriate utilisation of champions, our findings propose a high level of authority supports champions in their endeavours and avoids negative sentiments, such as frustrations, to be experienced by them.

(d) leadership status of the champion. A lack of formal leadership attached to the role bears the risk that the efforts of the champion will go unrecognised. The negative emotions attached to such an expectation lead to withholding of effort towards the innovation project by the champion.

(e) the organisational culture. A negative take on cultural issues, such as language aspects, issues of distrust and negative perceptions about existing and potential talent can adversely impact on emotional experiences of innovation champions.

(f) organisational events, such as mergers or acquisitions. Certain internal (organisational) and external (e.g., sociocultural) environmental factors have an equally adverse impact on the emotional experiences of innovation champions.

2) Identifying the emotions of (a) collegiality (b) pro-social emotions (c) disagreeableness and (d) effectuation as the prominent innovation champion's emotions that influence innovation outcomes. The identification of these emotions for their impact on innovation outcomes is discussed in the findings and discussions sections of the paper.

Championing behaviour is reflective of champion identity and the very specific dynamics within the environment, as well as the people that occupy it. It, therefore, remains difficult to predict future successful or value-adding behaviour by such individuals. 


\section{Practical Implications}

For practitioners, the contribution of this study is that they could evaluate the suitability of innovation champions' emotional competencies, for example, emotional intelligence, based on feedback from the innovation team and other psychometric assessments. Any evaluations are advised to place greater emphasis and weight on collegiality, pro-social emotions, disagreeableness and effectuation. Additionally, from an organisational innovation management perspective, these emotional dimensions could be monitored and encouraged to support positive innovation outcomes.

A means for supporting these emotional dimensions in an innovation champion is to control their antecedents, as listed in Figure 4. For example, formalisation of the champion role, i.e., appointment in the position of champion or even training for such a role would be greatly benefit from the management the emotional experiences of innovation champions and ensuring that these are better aligned to result in successful innovation outcomes. Howell and Boies (2004), discuss these issues, but do not provide a definite answer to the problem, as such, practical solutions rather than academic suggestions to the problem are required. In practice, the lack of solidification of the champion's role by way of proper identification, training, appointment, and utilisation could be ascribed to the fact that champions are a means to an end, and not the end itself. As such, a change in perspective is needed regarding innovation champions.

Furthermore, innovation champions could be assessed by way of 360-degree evaluations, where various stakeholders provide feedback on their experiences of engagement with the champion. The innovation champion should also receive feedback on this input to develop insight into his/her behaviour - positive or negative alike, and share the emotions that are triggering these behaviours with the leaders who are in charge of them. Potential champions, as well as those champions who have been assessed, then need to take the reported feedback into account before they decide to engage in further championing. Nonetheless, practitioners should, at all times, be cognisant of the fact that due to the discretionary nature of championing, a certain dynamic that could impact champion behaviours will always be present.

\subsection{Limitations and Future Research}

As an inductive study with a sample size of 20 champions within the financial services industry, our findings do not allow for a generalisation to other industries. This leaves room for deductive studies for future research. Such future research could also target proving links between specific emotions under certain organisational settings to innovation outcomes. Additionally, further research can confirm triggers or stimuli beyond the organisational factors that generate such emotions in champions and uncover how strategically that can be avoided for better innovation management.

Other areas for future research identified by this study include the question of whether championing behaviour can be linked to the construct of organisational citizenship behaviour. The (in)effectiveness of champions stays an elusive concept, often due to the informality of the champion's role and a lack of measurement of input. Another area of exploration would be the measurement of the perceptions of others (such as with a 360-degree evaluation or a multi-rater feedback system) as a means of gauging champion effectiveness, and increasing awareness among champions of their own behavioural impacts on others and project outcomes.

More research is also needed on the role of the champion's emotions and identity formation when role acting, with a focus on the identification of the champion with her/his role. 


\section{References}

Algoe, S. B. \& Fredrickson, B. L. (2011). Emotional fitness and the movement of affective science from lab to field. American Psychologist, 66(1), 35-42. https://doi.apa.org/doi/10.1037/ a0021720

Arntz, W., Chasse, B., \& Vicente, M. (2005). What the bleep do we know!? Discovering the endless possibilities for altering your everyday reality. Deerfield Beach: Health Communications.

Ashkanasy, N. M., \& Ashton-James, C. E. (2005). Emotion in organisations: A neglected topic in psychology, but with a bright future. In G. P. Hodgkinson \& J. K. Ford (Eds.), International review of industrial and organizational psychology, (pp. 221-268). Chichester: John Wiley \& Sons.

Bankins, S., Denness, B., Kriz, A., \& Molloy, C. (2016). Innovation agents in the public Sector: Applying champion and promotor theory to explore innovation in the Australian Public Service. Australian Journal of Public Administration, 76(1), 122-137. https://doi.org/10.1111/1467-8500. 12198

Barnhill, C. R., Smith, N. L., \& Oja, B. D. (2021). Creative and innovative teams. In C. R. Barnhill, N. L. Smith \& B. D. Oja (Eds.), Organizational behavior in sport management (pp. 165-173). Cham: Springer Nature Switzerland

Bartlett, D. (2017). Champions of local authority innovation revisited. Local Government Studies, 43(2), 142-149. https://doi.org/10.1080/03003930.2016.1245184

Bates, T., Chedister, B., \& Snow, J. (2021). On being stretch Armstrong: Innovating successfully inside bureaucratic organizations. In Z. S. Davis, F. Gac, C. Rager, P. Reiner, \& J. Snow (Eds.), Strategic latency unleashed: The role of technology in a revisionist global order and the implications for special operations forces (pp. 305-321). Livermore: Centre for Global Security Research.

Beckett, R. C., \& Berendsen, G. (2015). The complex innovation champion - Three roles facilitating innovations. 16th International CINet Conference - Pursuing Innovation Leadership, (September), 1-13. Stockholm.

Bergh, Z. (2014). Personality recognised in traits. In Z. Bergh, \& D. Geldenhuys (Eds.), Psychology in the work context (pp. 351-374). (5th ed.). Cape Town: Oxford University Press.

Birkinshaw, J., Hood, N., \& Young, S. (2005). Subsidiary entrepreneurship, internal and external competitive forces, and subsidiary performance. International Business Review, 14(2), 227-248. https://doi.org/10.1016/j.ibusrev.2004.04.010

Birkinshaw, J., Hamel, G., \& Mol, M. J. (2008). Management innovation. Academy of Management Review, 33(4), 825-845. https://doi.org/10.5465/amr.2008.34421969

Bishop, J. (2009). Ethical sharing and reuse of qualitative data. Australian Journal of Social Issues, 44(3), 255-272. https://doi.org/10.1002/j.1839-4655.2009.tb00145.x

Burnard, P., Gill, P., Stewart, K., Treasure, E., \& Chadwick, B. (2008). Analysing and presenting qualitative data. British Dental Journal, 204(8), 429-432. https://doi.org/10.1038/sj.bdj.2008. 292

Cilliers, J., \& Aucoin, C. (2016). Economics, governance and instability in South Africa. SSRN Electronic Journal, 2030(June), 1-24. https://doi.org/10.2139/ssrn.2819050

Coakes, E., \& Smith, P. (2007). Developing communities of innovation by identifying innovation 
champions. The Learning Organization, 14(i), 74-85. https://doi.org/10.1108/09696470710718366

Corti, L \& Bishop, L. (2005). Strategies in teaching secondary analysis of qualitative data. Forum Qualitative Social Research, 6(1), Art. 47, 1-27. https://doi.org/10.17169/fqs-6.1.509

Creswell, J. W., \& Clark, V. L. P. (2011). Designing and conducting mixed method research. (2nd ed.). Los Angeles: Sage Publications, Inc.

Curtis, M. B., Chui, L., \& Pavur, R. J. (2020). Intention to champion continuous monitoring: A study of intrapreneurial innovation in organizations. Journal of Emerging Technologies in Accounting, 17(2), 119-140. https://doi.org/10.2308/jeta-2020-014

Damanpour, F., \& Schneider, M. (2006). Phases of the adoption of innovation in organizations: Effects of environment, organization and top managers. British Journal of Management, 17(3), 215-236. https://doi.org/10.1111/j.1467-8551.2006.00498.x

Dharani, B. (2021). At the intersection of happiness and contentment at work. In J. Marques (Ed.), The Routledge companion to happiness at work (pp. 61-75). New York: Routledge.

Esteves, J. M., \& Pastor-Collado, J. A. (2002). Understanding the ERP Project champion role and its criticality. In Association for Information Systems Electronic Library (Ed.), Proceedings of the European Conference on Information Systems, 6-8 June 2002, Gdansk (pp. 1077-1086).

Fielding, N. G. \& Fielding, J. L. (2008). Resistance and adaptation to criminal identity: Using secondary analysis to evaluate classic studies of crime and deviance. Sociology, 34(4), 671-689. http://dx.doi.org/10.1177/S0038038500000419

Garud, R., Tuertscher, P., \& Van de Ven, A. H. (2015). Business innovation processes. In C. E. Shalley, M. A. Hitt, \& J. Zhou (Eds.), The Oxford handbook of creativity, innovation, and entrepreneurship (pp. 339-352). New York: Oxford University Press.

Gemünden, H. G., Salomo, S., \& Hölzle, K. (2007). Role models for radical innovations in times of open innovation. Creativity and Innovation Management, 16(4), 408-421. https: //doi.org/10.1111/j.1467-8691.2007.00451.x

Gendron, B. (2004). Why emotional capital matters in education and labour? Toward an optimal explanation of human capital and knowledge management. Les Cahiers de la Maison des Sciences Economiques, Serie Rouge(113). Paris: Université Panthéon-Sorbonne.

Goulding, C. (2005). Grounded theory, ethnography, and phenomenology. A compound analysis of three different strategies for marketing research. European Journal of Marketing, 39(3/4), 294-308. https://doi.org/10.1108/03090560510581782

Govindarajan, V., \& Trimble, C. (2010). The other side of innovation: Solving the execution challenge. Boston: Harvard Business Review Press.

Heaton, J. (2008). Secondary analysis of qualitative data: an overview. Historical Social Research, 33(8), 33-45. https://doi.org/10.12759/hsr.33.2008.3.33-45

Hendy, J., \& Barlow, B. (2012). The role of the organizational champion in achieving health system change. Social Science \& Medicine, 74(3), 348-355. https://doi.org/10.1016/j.socscimed. 2011.02.009

Heng, M. S. H., Trauth, E. M., \& Fischer, S. J. (1999). Organisational champions of IT innovation. Accounting Management and Information Technologies, 9(3), 193-222. https: //doi.org/10.1016/S0959-8022(99)00008-9 
Ho, K. H. M., Chiang, V. C. L., \& Leung, D. (2017). Hermeneutic phenomenological analysis: the 'possibility' beyond 'actuality' in thematic analysis. Journal of Advanced Nursing, 73(7).

Howell, J. M. (2005). The right stuff: Identifying and developing effective champions of innovation. Academy of Management Perspectives, 19(2), 108-119. https://doi.org/10.5465/ame.2005. 16965104

Howell, J. M., \& Boies, K. (2004). Champions of technological innovation: the influence of contextual knowledge, role orientation, idea generation, and idea promotion on champion emergence. The Leadership Quarterly, 15(1), 123-143. https://doi.org/10.1016/j.leaqua.2003.12.008

Howell, J. M., Shea, C. M., \& Higgins, C. A. (2005). Champions of product innovations: Defining, developing, and validating a measure of champion behaviour. Journal of Business Venturing, 20(5), 641-661. https://doi.org/10.1016/j.jbusvent.2004.06.001

Izard, C.E. (2007). Basic emotions, natural kinds, emotion schemas, and a new paradigm. Association for Psychological Science, 2(3), 206-280. https://doi.org/10.1111\%2Fj.1745-6916. 2007.00044.x

Jenssen, J. I. \& Jørgensen, G. (2004). How do corporate champions promote innovations? International Journal of Innovation Management, 8(1), 63-86. https://doi.org/10.1142/S1363919604000964

Johnson, K., Hays, C., Center, H. \& Daley, C. (2004). Building capacity and sustainable prevention innovations: A sustainability planning model. Evaluation and Program Planning, 27(2), 135-48 . https://doi.org/10.1016/j.evalprogplan.2004.01.002

Kelley, D., \& Lee, H. (2010). Managing innovation champions: The impact of project characteristics on the direct manager role. Journal of Product Innovation Management, 27(7), 1007-1019. https://doi.org/10.1111/j.1540-5885.2010.00767.x

Kelley, T. with Littman, J. (2006). The ten faces of innovation: IDEO's strategies for beating the devil's advocate and driving creativity throughout your organization. London: Profile Books.

Klein, K. J., \& Sorra, J. S. (1996). The challenge of innovation implementation. Academy of Management Review, 21(4), 1055-1080. https://doi.org/10.5465/amr.1996.9704071863

Klerkx, L., Adjei-Nsiah, S., Adu-Acheampong, R., Saïdou, A., Zannou, E., Soumano, L., SakyiDawson, O., Van Paassen, A., \& Nederlof, S. (2013). Looking at agricultural innovation platforms through an innovation champion lens: An analysis of three cases in West Africa. Outlook on Agriculture, 42(3), 185-192. https://doi.org/10.5367/oa.2013.0137

Klerkx, L., \& Aarts, N. (2013). The interaction of multiple champions in orchestrating innovation networks: Conflicts and complementarities. Technovation, 33(6-7), 193-210. https://doi.org/10. 1016/j.technovation.2013.03.002

Lauterbach, A. A. (2018). Hermeneutic phenomenological interviewing: Going beyond semistructured formats to help participants revisit experience. Qualitative Report, 23(11), 2883-2898. https://doi.org/10.46743/2160-3715/2018.3464

Lawler, E.J. (2018). The affect theory of social change. In Burke, P. J. (Ed.) Contemporary social psychological theories (pp. 225-248). Stanford: Stanford University Press.

Leiringer, R. \& Cardellino, P.(2008). Tales of the expected: Investigating the rhetorical strategies of innovation champions. Construction Management and Economics, 26(10), 1043-1054. https: //doi.org/10.1080/01446190802389394 
Markham, S. K. (2013). The impact of front-end innovation activities on product performance. Journal of Product Innovation Management, 30(SUPPL 1), 77-92. https://doi.org/10.1111/jpim.12065

Maslach, C., Schaufeli, W. B., \& Leiter, M. P. (2001). Job burnout. Annual Review of Psychology, 52(1), 397-422. https://doi.org/10.1146/annurev.psych.52.1.397

Meyer, J. P., \& Allen, N. J. (1991). A three-component conceptualization of organizational commitment. Human Resources Management Review, 1(1), 61-89. https://doi.org/10.6007/IJARBSS/v6i12/2464

Meyer, J. P., Stanley, D. J., Herscovitch, L., \& Topolnytsky, L. (2002). Affective, continuance, and normative commitment to the organization: A meta-analysis of antecedents, correlates, and consequences. Journal of Vocational Behavior, 61(1), 20-52. https://doi.org/10.1006/jvbe.2001. 1842

Nahapiet, J., \& Ghoshal, S. (1998). Social capital, intellectual capital, and the organizational advantage. Academy of Management Review, 23(2), 242-266. https://doi.org/10.5465/amr. 1998.533225

Natalya Sergeeva. (2016). What makes an "innovation champion"? European Journal of Innovation Management, 19(1), 72-89. https://doi.org/10.1108/EJIM-06-2014-0065

Organ, D. W. (1997). Organizational citizenship behavior: It's construct clean-up time. Human Performance, 10(2), 85-97. https://doi.org/10.1207/s15327043hup1002_2

Østergaard, K. (2019). Transforming legacy organizations: Turn your established business into an innovation champion to win the future (pp. 1-2). Chichester: Wiley.

Papadakis, V., \& Bourantas, D. (1998). The chief executive officer as corporate champion of technological innovation: an empirical investigation. Technology Analysis and Strategic Management, 10(1), 89-110. https://doi.org/10.1080/09537329808524306

Pinto, J. K., \& Patanakul, P.(2015). When narcissism drives project champions: A review and research agenda. International Journal of Project Management, 33(5), 1180-1190. https: //doi.org/10.1016/j.ijproman.2015.01.013

Poole, M. S. (2004). Central issues in the study of change and innovation. In M. S. Poole, \& A. $\mathrm{H}$. van de Ven (Eds.), Handbook of organizational change and innovation (pp. 3-31). New York: Oxford University Press, Inc.

Read, S., Song, M. \& Smit, W. (2009). A meta-analytic review of effectuation and venture performance. Journal of Business Venturing, 24(6), 573-587. https://doi.org/10.1016/j.jbusvent. 2008.02.005

Röst, K., Hölzle, K., \& Gemünden, H. G. (2007). Promotors or champions? Pros and cons of role specialization for economic process. Schmalenbach Business Review, 59(4), 340-363. https://doi.org/10.5167/uzh-68489

Rothwell, R. (1992). Successful industrial innovation: Critical factors for the 1990s. R\&D Management, 22(3), 221-239. https://doi.org/10.1111/j.1467-9310.1992.tb00812.x

Ryan, P. M. (2014). Dictionary of emotions: Words for feelings, moods and emotions. Dublin: Pamaxamal.

Saldaña, J. (2013). The coding manual for qualitative researchers. London: Sage

Sander, D. \& Scherer, K. R. Eds. (2006). The Oxford companion to emotion and the affective 
sciences. Oxford: Oxford University Press.

Sergeeva, N. (2016). What makes an "innovation champion"? European Journal of Innovation Management, 19(1), 72-89. https://doi.org/10.1108/EJIM-06-2014-0065

Shane, S., Venkataraman, S., \& MacMillan, I. (1995). Cultural differences in innovation championing strategies. Journal of Management, 21(5), 931-952. https://doi.org/10.1016/ 0149-2063(95)90048-9

Shaw, E. K., West, D. R., Crabtree, B. F., Nease, M. D., Tutt, B., \& Nutting, P.A. (2012). The role of the champion in primary care change efforts: From the state networks of Colorado Ambulatory Practices and Partners (SNOCAP). Journal of the American Board of Family Medicine, 25(5), 676-685. https://doi.org/10.31221jabfm.2012.05.110281.

Shea, C. M. (2021). A conceptual model to guide research on the activities and effects of innovation champions. Implementation Research and Practice, 2(1), 1-13. https://doi.org/10. $1177 / 2633489521990443$

Shea, M. \& Belden, C. M. (2016). What is the extent of research on the characteristics, behaviors, and impacts of health information technology champions? A scoping review. BMC Medical Informatics and Decision Making, 16(2), 1-17. https://doi.org/10.1186/s12911-016-0240-4

Singh, S., Dhir, S., Gupta, A., Das, V. M., \& Sharma, A. (2020). Antecedents of innovation implementation: a review of literature with meta-analysis. Foresight, 23(3), 273-298. https: //doi.org/10.1108/FS-03-2020-002

Smith, C. A., Organ, D. W., \& Near, J. P. (1983). Organizational citizenship behaviour: Its nature and antecedents. Journal of Applied Psychology, 68(4), 653-663. https://doi.org/10. 1037/0021-9010.68.4.653

Smith, D. J. (2007). The politics of innovation: Why innovations need a godfather. Technovation, 23(3), 96-104. https://doi.org/10.1016/j.technovation.2006.05.001

Smith, T.W. (2016). The book of human emotions: An encyclopedia of feeling from anger to wanderlust. London: Profile Books.

Starks, H., \& Trinidad, S. B. (2007). Choose your method: A comparison of phenomenology, discourse analysis, and grounded theory. Qualitative Health Research, 17(10), 1372-1380. https: //doi.org/10.1177/1049732307307031

Swart-Opperman, C., \& April, K. A. (2018). Innovation team composition: The enabling role of the individual emotive outlook. African Journal of Business Management, 12(12), 357-371. https://doi.org/10.5897/ajbm2018.8547

Taylor, A. (2007). Sustainable urban water management champions: What do we know about them? Proceedings of the $13^{\text {th }}$ International Rainwater Catchment Systems Conference and the $5^{\text {th }}$ International Water Sensitive Urban Design Conference, 21-23 August, Sydney, Australia.

Yoho, K. D., Ford, R., Edvardsson, B., \& Dahlinger, F. (2018). Moving “The Greatest Show on Earth": W.C. Coup as an innovation champion. Journal of Management History, 24(1), 76-98. https://doi.org/10.1108/JMH-07-2017-0035

Yunicheva, R., \& Luna. A. E. (2012). Composition of Skunk works teams. Master's Dissertation in Strategic Leadership, Halmstad University, Halmstad. Accessed $28^{\text {th }}$ July 2017. https://www. diva-portal.org/smash/get/diva2:538736/FULLTEXT01.pdf 
Wade, V., \& Eliott, J. (2012). The role of the champion in telehealth service development: A qualitative analysis. Journal of Telemedicine and Telecare, 18(8), 490-492.https://doi.org/10. 1258/jtt.2012.gth115

Walter, A., Parboteeah, K. P., Riesenhuber, F., \& Hoegl, M. (2011). Championship behaviours and innovation success: An empirical investigation of university spin-offs. Journal of Product Innovation Management, 28(4), 586-598. https://doi.org/10.1111/j.1540-5885.2011.00826.x

Weiss H.M. \& Cropanzano, R. (1996). Affective events theory: A theoretical discussion of the structure, causes and consequences of affective experiences at work. In L.L. Cummings \& Staw, B.M. Eds. Research in Organizational Behavior, 18, 1-74, Greenwich: JAl Press.

Wästerfors, D., Åkerström, M. \& Jacobsson, K. (2014). Reanalysis of qualitative data. In Flick, U. (Ed.). The SAGE handbook of qualitative data analysis (pp. 467-480). Thousand Oaks: Sage.

White, C.L. \& McGowan, N. (2011). Nurse champions: A key role in bridging the gap between research and practice. Journal of Emergency Nursing, 37(4), 386-387. https://doi.org/10.1016/j. jen.2011.04.009

Zelenski, J. M., Murphy, S. A., \& Jenkins, D. A. (2008). The happy-productive worker thesis revisited. Journal of Happiness Studies, 9(4), 521-537. https://doi.org/10.1007/s10902-008-9087-4 


\section{Biographies}

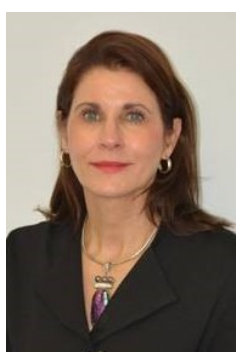

Christina Swart-Opperman. Dr Christina Swart-Opperman, lectures at universities on invitation and supervises master's and Doctoral theses in organisational behaviour and people management areas. Christina has extensive experience in the field of human resources consulting, and as an industrial psychologist. Christina serves and advises boards in her area of expertise. Christina holds Doctorates in Industrial Psychology (University of Northwest) and Business Administration (University of Cape Town).

CRediT Statement: Conceptualization, Methodology, Software, Validation, Formal Analysis, Investigation, Data curation, Writing- Original draft preparation, Investigation, Software.

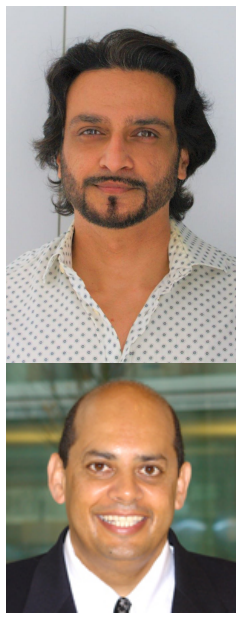

Babar Dharani. Dr. Babar Dharani is a Senior Lecturer in the Allan Gray Centre for ValuesBased Leadership at the Graduate School of Business of the University of Cape Town (South Africa) specializing in Leadership and Happiness. He is a Business Finance Professional and a Fellow of the Institute of Chartered Accountancy in England and Wales. Having held leadership positions in finance in the Diamond industry, his prime area of interest in academia is Leadership Development, focusing on emotions in organizations, and regards diversity and inclusion as one of the fundamental pillars for happiness at work.

CRediT Statement: Writing- Reviewing and Editing, Visualization.

Kurt April. Kurt April is currently the Allan Gray Chair, an Endowed Professorship, specialising in Leadership, Diversity \& Inclusion and Director of the Allan Gray Centre for Values-Based Leadership at the Graduate School of Business, University of Cape Town (South Africa, 1998present), is Adjunct Faculty of Saïd Business School (University of Oxford, UK, 2000-present), and is a Faculty Member of Duke Corporate Education (Duke University, USA, 2008-present). Previously, he was a Research Fellow of Hult-Ashridge Business School (UK, 2004-2016), Visiting Professor at London Metropolitan University (UK, 2014-2017), Visiting Professor at Rotterdam School of Management (Erasmus University, Netherlands, 2001-2013), and Visiting Professor in the Faculty of Economics \& Econometrics (University of Amsterdam UvA, Netherlands, 2004-2007).

CRediT Statement: Supervision, Project Administration. 